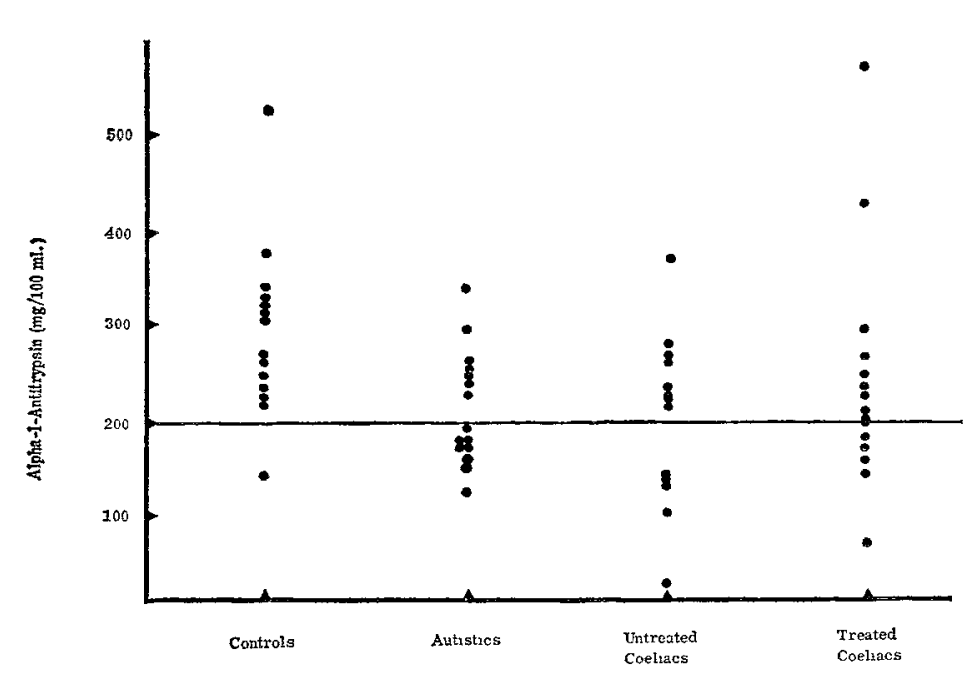

Alpha-1-antitrypsin levels in controls, autistic children, and children with untreated and with treated coeliac disease.

protecting tissues against enzymatic attack, and its serum level does rise as part of an inflammatory response. ${ }^{4}$ It is possible that a low level of alpha-1-antitrypsin may predispose to the small-intestinal damage which occurs in cœliac disease. It is more difficult to speculate concerning the significance of a reduction in serum alpha-1-antitrypsin in 8 autistic children, none of whom had evidence of cœliac disease.

Studies of the level of serum alpha-1-antitrypsin in larger groups of children and their families with these disorders will be of interest.

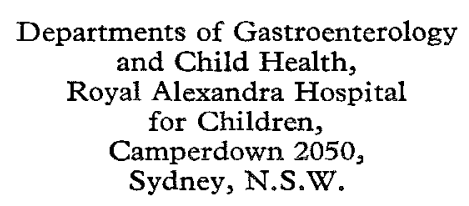

JOHN WALKER-SMITH JUDITH ANDREWS.

\section{ANTIBODY RESPONSE RELATED TO HL-A ANTIGENS IN HODGKIN'S DISEASE AND OTHER LYMPHOMAS}

SIR,-Hodgkin's disease is a disorder accompanied by abnormalities of cellular immune mechanisms, while humoral immunity seems to be relatively well preserved. ${ }^{5-7}$ Immune deficiency is also found in other lymphomas.?

38 patients (29 with Hodgkin's disease, 9 with other lymphomas) and 27 healthy unrelated volunteers were vaccinated with an influenza-A Hong Kong vaccine and typed for HL-A antigens. Serum antibodies were measured by routine hæmagglutination inhibition (H.I.) assay and complement-fixation test (C.F.). Neither patients nor controls showed an increase or appearance of antibody in C.F., supporting the fact that no clinical influenza infections occurred. ${ }^{8}$ All 27 control subjects showed a fourfold rise in titre or greater, measured by H.I., but 6 patients with Hodgkin's disease and 2 patients with other lymphomas did not respond with demonstrable antibody formation.

The incidence of non-response in control subjects was, using the $2 \times 2$ table, significantly different from that in Hodgkin's disease $(P=0.01)$ and from that in other lymphomas $(P=0.05)$.

Non-response after vaccination was not significantly associated with a low immunoglobulin level, not with an

4. Talamo, R. C., Langley, C. E., Barber, J. C., Berman, M. B., Hyslop, N. E. Pediat. Res. 1972, 6, 119.

5. Aisenberg, A. C. Cancer Res. 1966, 26, 1152.

6. Schneider, M., Schwartzenberg, L., Amiel, J. L., Hayat, M., Mascaro, G., Otmezguine, Y., Mathé, G. Presse méd. 1970, 78, 1769.

7. Miller, D. G. Cancer Res. $1968,28,1441$.

8. Debré, R., Celers, J. Clinical Virology. Philadelphia, 1970. absence of a demonstrable influenza Hong Kong antibody titre in H.I. before immunisation. There was an association between non-response and irradiation during the immunisation period; however, no association was present with treatment with prednisone or cytostatic drugs. In Hodgkin's disease lack of antibody formation was not related to clinical staging or histological grading. The serum-IgM level in patients with Hodgkin's disease, especially in non-responders, was (not significantly) lower than that in control subjects. The IgG, IgA, and IgD levels showed no important differences.

Both in patients with Hodgkin's disease and in the combined group of patients with Hodgkin's disease and other lymphomas, a normal distribution of HL-A antigens was found. 9

In all lymphoma patients without antibody formation after influenza vaccination, the $\mathrm{HL}-\mathrm{A} 12$ frequency was $62 \%$ and in patients with a normal humoral immune response it was only $13 \%$. This difference is significant $(P=0.02)$. The difference becomes more significant $(P<0.01)$ if HL-A12 frequency is compared in patients who were not irradiated during the immunisation period: $80 \%$ in patients without antibody formation, $14 \%$ in patients with antibody formation. In patients with Hodgkin's disease, not irradiated during the immunisation period, HL-A12 frequency was $75 \%$ when antibody formation could not be demonstrated and $14 \%$ when humoral response was present. This difference is significant $(\mathrm{P}<0.01)$.

In the mouse a linkage between the $\mathrm{H} 2 \mathrm{q}$ allele and the capacity to produce certain antibodies is demonstrated, ${ }^{10}$ while in man such a relationship has not yet been found.

This study suggests that a relationship exists between antibody formation and HL-A pattern in patients with Hodgkin's disease and other lymphomas. This phenomenon is not necessarily specific for lymphomas: it might also be demonstrable in other states of immune deficiency.

For help and advice I thank N. Masurel, D. A. G. Tyrrell, J. D. Holtzer, E. Borst-Eilers, B. J. M. Zegers, W. Fidler, A. A. Huith, M. Moes, P. C. Sander, J. K. Schot, and the National Institute of Public Health.

Blood Bank and Department of Hæmatology,

Academisch Ziekenhuis,

Utrecht, The Netherlands.

J. P. H. B. Sybesma.

\section{HOW INFECTIOUS IS GONORRHEA ?}

SIR,-Four youths had intercourse with the same girl in quick succession. Two caught gonorrhwa, the other two did not.

\begin{tabular}{cccccc} 
Age & \multicolumn{2}{c}{ Intercourse } & Urination & First & Gonococcal \\
after & seen & discharge \\
19 & July 26 & 2nd & 2 minutes & Aug. 3 & Aug. 12 (17th day) \\
19 & July 26 & 1st & 1 hour & Aug. 3 & July 31 (5th day) \\
18 & July 26 & 4th & ? & Aug. 3 & $\ldots$ \\
16 & July 26 & 3rd & $15-20$ sec. & Aug. 3 & $\ldots$
\end{tabular}

Burgess ${ }^{11}$ reported that immediate post-coital urination may prevent gonococcal urethritis, and described a case of gonococcal tysonitis without urethritis. American authors ${ }^{12}$ estimated-from the activities of the crew of an aircraft carrier visiting the Philippines-the risk of men acquiring gonorrhoea from infected females as about $22 \%$. How many of those men who "escape" the infection are really carriers? It appears that the more thoroughly asympto-

9. Sybesma, J. P. H. B., Borst-Eilers, E., Holtzer, J. D., Moes, M., Peilage, E., De Planque, B. A. Vox Sang. 1972, 22, 319.

10. McDevitt, H. O., Benacerraf, B. Adv. Immun. 1964, 11, 65.

11. Burgess, J. A. Br. F. vener. Dis. $1971,47,40$.

12. Holmes, K. K., Johnson, D. W., Trostle, H. J. Am. F. Epidem. $1970, \mathbf{9 1}, 170$. 